\title{
Examination of university students' fear of negative evaluation and academic dishonesty tendencies
}

\author{
Berkan Bozdağ $\breve{~}^{*}$ \\ Faculty of Sport Science, Yozgat Bozok University, Yozgat, Turkey
}

ORCID: 0000-0003-3657-4359

\section{Article history}

Received:

16.09.2020

Received in revised form: 25.11.2020

Accepted:

13.01.2021

Key words:

Fear of negative evaluation; Academic dishonesty:

University student;

Sports
The aim of this study is to examine the relationship between university students' fear of negative evaluation and their academic dishonesty tendencies and to compare them in terms of various variables. The sample of the study carried out in the relational screening model consists of 306 students, who were selected by the easily accessible sampling method among the university students studying at Yozgat Bozok University, Turkey in the academic year 2019-2020. "Personal Information Form", "Academic Dishonesty Tendencies Scale", "Brief Fear of Negative Evaluation Scale" were used as data collection tools in the study. The data in the research were analyzed using the SPSS 22.0 package program. As a result of the analysis made with the Kolmagorov Smirnov test, it was found that the data were normally distributed. Independent-Samples T Test, One-Way ANOVA, Pearson Correlation and Simple Linear Regression Analysis were used to analyze the data. As a result of the analyses made, it was determined that there was no significant difference between the fear of negative evaluation and the sub-dimensions of the academic dishonesty scale in terms of gender. It was determined that the mean scores of sedentary students were significantly higher than the mean scores of the students doing sports in the dishonesty in citation sub-dimension of the academic dishonesty tendencies scale. As a result, it was determined that there is a low-level positive relationship between university students' fear of negative evaluation and their dishonesty tendency. As students' fear of negative evaluation increases, academic dishonesty tendencies also increase.

\section{Introduction}

Academic dishonesty has become a rising trend among university students with the rapid development of technology today (Murdock \& Anderman, 2006). Academic dishonesty is frequently resorted to by university students, it has an increasing trend and thus poses a big problem (Eminoğlu \& Nartgün, 2009). In particular, with the recent pandemic and emergency remote teaching conditions it is witnessed that the issue has gained more importance and thereupon it now requires more attention of the stakeholders. In addition to looking at the relevant source(s) in the exams, using assignment and projects without permission and unauthorized copying and fabrication of studies with a known source are also included in this

\footnotetext{
*Correspondency: brknbozdag@gmail.com
} 
scope (Colnerud \& Rosanderi, 2009). In fact, academic dishonesty is all of the illegal behaviors such as cheating in exams, plagiarizing assignment, changing exam papers, and changing research results (Aluede, Omoregie \& Osa-Edoh, 2006). Academic dishonesty is a general term that includes plagiarism. Plagiarism, on the other hand, is explained in different sentences in the literature, but all definitions are emphasized on the feature of "using someone else's ideas and opinions without reference" (Ünal \& Uçak, 2017).

Various policies are set to prevent academic dishonesty in schools. Especially in universities, applying punishments, explaining the rules clearly to students in various ways, and treating them equally are among the behaviors that aim to reduce dishonesty behavior (Gerdeman, 2000). On the other hand, the difficulty levels of exams, not applying punishments after dishonesty, measuring tools such as tests, halls unsuitable for exams, applying the same exam to different classes, applying exams with less chance of being caught while cheating increase dishonesty (Maramark \& Maline, 1993). In addition to exams, another area where dishonesty is observed is assignment and projects. An assignment that is not suitable for students' levels, assignments that are given too often, that do not appeal to the field of interest may cause the very problem to occur and students' reporting directly to the source, instructors' not checking the assignments givenand/or their giving the same assignments every year, and assignments based on result rather than the process cause students to turn to academic dishonesty (Odabaşı, Birinci, Kılıçer, Şahin, Akbulut \& Şendağ, 2007).

Individuals who are involved in academic dishonesty think that this is a normal or acceptable behavior (Crown \& Spiller, 1998). Gerdeman (2000) lists the individual factors that underlie individuals' tendency to academic dishonesty as academic achievement, age, social activities, branch and gender. Peers' behaviours and attitudes affect students' misbehaviour and academically misconduct decisions. It was concluded that students were prone to academic dishonesty since they constantly follow each other. Although academic achievement is not the only factor affecting a person's acceptance and survival in a social environment, it can actually constitute a factor. A student whose academic achievement is not at the desired level may feel uncomfortable in some cases and experience some problems arising from this (Ömür, Aydın \& Argon, 2014). According to the results of a study conducted by Bozdoğan \& Öztürk (2008) to reveal the reasons for teacher candidates to cheat, it is seen that one of the reasons that pushes teacher candidates to cheat is failing the class and the fear of being brought disgrace upon their environment and family. It was thought that students with these and similar concerns would be able to perform actions defined as academic dishonesty, such as cheating and plagiarism, rather paradoxically in order to gain the appreciation of the environment and to protect and strengthen their place in their social environment, even if they do not approve of participating in these acts. However, Nichols (2014) argues that lack of information and indolence, procrastination, easiness of cheating, family pressure, and fear of negative evaluation are among the triggering factors of the academic dishonesty.

Fear of negative evaluation is the state of being concerned about others' evaluations, being afraid of their negative evaluations, and thinking that they will give others negative information about themselves (Watson \& Friend, 1969). Individuals with fear of negative evaluation are individuals who have low self-esteem, and they are the ones who do not want to leave an unwanted impact on their social environment or be socially excluded, and hence constantly worry about not leaving a negative impression to others (Weeks, Heimberg, Fresco, Hart, Turk, Scneider \& Liebowitz, 2005). Monfries and Kafer (1994 please also include the page number if this is a direct quotation) argue that fear of negative evaluation can be defined as "the awareness that the individual is revealed to have a low level and that the 
evaluation result can negatively affect the individual" while fear of negative evaluation by the social structure in which s/he belongs to is a social anxiety, which causes the individual to be excessively and constantly worried that he will be criticized in a disparaging and hostile way by others. This situation also causes the individual to develop conditional beliefs on his own. For example, an individual who experiences fear of negative evaluation may have the belief that a social activity in which s/he takes part will be evaluated in a way that $\mathrm{s} / \mathrm{he}$ does not want, desire, or accept (Çetin, İlhan \& Yılmaz, 2014).

It can be said that sports activities come first among social activities. According to Cihan and Ilgar (2018), sports activities are of great importance in increasing the life skills of adolescents. It was observed that there is a decrease in the social anxiety of individuals participating in sports activities (İnan, İnan, Varol, Çolakoğlu \& Çolakoğlu, 2019). The main feature of the term social anxiety is defined as a situation involving fear of multiple situations through which the person will be negatively evaluated by others and worries that they will be humiliated, embarrassed or behaved in a way that makes him/her ridiculous (Dilbaz, 1997; Çetin, Doğan \& Sapmaz, 2010). Fear of negative evaluation is the feeling of fear and anxiety that emerges in line with the belief that a person will make mistakes, be ridiculed and disgraced in situations where s/he should perform in social environments in which other people are also present (Irmak, 2015). Individuals are afraid that others will have a negative impression of them in social situations and therefore will not be respected (Subaş1, 2009). As a matter of fact, Individuals care about the impressions they leave on others and how they are evaluated by them when they enter into social interaction, and their evaluation expectations can be positive or negative (Çam, Sevimli \& Yerlikaya, 2010).

It is well known that people living in a social network may experience concerns such as disapproval, misunderstanding, and negative evaluation by other individuals in the society. These anxious situations negatively affect the lives of individuals, and may at times take wrong steps to turn the situation into a positive one. In order not to be negatively evaluated by the society, it can be seen that individuals commit academic dishonesty during their work or student life. Individuals want to be successful and do not want to be evaluated negatively (Kıral \& Saracaloğlu, 2018).

In this context, during the university period, when the individual leaves the family and opens up to the outside world, especially when the relationships with his/her social environment differ and emotional changes begin, students care very much about the impressions they leave on others and how they are evaluated by them. However, in some cases where academic achievement of the students is not at the desired level, they may experience concerns such as disapproval, misunderstanding, and negative evaluation in their social environment. It can be seen that individuals who want to get rid of these anxious situations attempt academic dishonesty by looking for different solutions even if they do not approve. When the literature is examined, it is seen that the number of studies on fear of negative evaluation and academic dishonesty tendencies is quite limited. In this context, the negative evaluation and academic dishonesty tendencies of university students, who are the adults of our future, are an object of interest.

Therefore, in the present study, it was aimed to examine the relationship between university students' fear of negative evaluation and academic dishonesty tendencies and to compare them in terms of various variables. For this purpose, answers to the following questions were sought in the research: 
(1) Does university students' fear of negative evaluation differ according to gender, state of doing sports and grade level?

(2) Do university students' academic dishonesty tendencies differ according to gender, state of doing sports and grade level?

(3) Is there a relationship between university students' fear of negative evaluation and their academic dishonesty tendencies?

\section{Method}

\section{Research Model}

In the study, it was aimed to examine the fear of negative evaluation and academic dishonesty tendencies of university students and to determine whether there was a significant difference between the demographic characteristics of the students. In this context, the research is a relational screening model. In this approach, which is based on investigating and describing a past or present situation as it is, the event, phenomenon or situation that is the subject of the research is tried to be explained as it is (Karasar, 2015). The independent variables of the study are the university students' gender, doing sports and grade level. Its dependent variables are fear of negative evaluation and academic dishonesty tendencies.

\section{Research Group}

The sample of the study consists of 306 university students, 171 male and 135 female, studying at Yozgat Bozok University in the academic year 2019-2020. Participants were determined using an easily accessible sampling method. Participation in the study was on a voluntary basis. Distribution of the students participating in the research by gender, state of doing sports and grade level were presented in Table 1.

Table 1. Frequency and percentage distributions related to students' demographic characteristics

\begin{tabular}{|c|c|c|c|}
\hline Variable & Groups & $\mathbf{N}$ & $\%$ \\
\hline \multirow{3}{*}{ Gender } & Female & 135 & 44.1 \\
\hline & Male & 171 & 55.9 \\
\hline & Total & 306 & 100 \\
\hline \multirow{3}{*}{ State of Doing Sports } & Sedentary & 225 & 73.5 \\
\hline & Athletes & 81 & 26.5 \\
\hline & Total & 306 & 100 \\
\hline \multirow{5}{*}{ Grade Level } & $1^{\text {st }}$ & 89 & 29.1 \\
\hline & $2^{\text {nd }}$ & 46 & 15.0 \\
\hline & $3^{\text {rd }}$ & 38 & 12.4 \\
\hline & $4^{\text {th }}$ & 133 & 43.5 \\
\hline & Total & 306 & 100 \\
\hline
\end{tabular}

When Table 1 is examined, it is seen that $55.9 \%(n=171)$ of the students participating in the study are male and $44.1 \%(n=135)$ are female. While $73.5 \%(n=225)$ of the students are sedentary students, $26.5 \%(n=81)$ of them are athletes. $29.1 \%(n=89)$ of the students study in the 1 st grade, $15 \%(n=46)$ the 2 nd grade, $12.4 \%(n=38)$ the $3 r d$ grade, $43.5 \%(n=133)$ study in the 4 th grade. 


\section{Data Collection Tools}

"Academic Dishonesty Tendencies Scale" to determine students' academic dishonesty tendencies, the "Brief Fear of Negative Evaluation Scale" to measure students' fear of negative evaluation, and the "Personal Information Form" prepared by the researcher to obtain the data of demographic variables were used as a data collection tools in the study.

\section{Academic dishonesty tendencies scale}

The "Academic Dishonesty Tendencies Scale" developed by Eminoğlu and Nartgün (2009) was used to determine the academic dishonesty tendencies of teacher candidates. The scale consists of four sub-dimensions including 22 items. The scale is a 5-point Likert type scale: (1) Strongly Disagree, (2) Disagree, (3) Undecided, (4) Agree, (5) Strongly Agree. The construct validity of the scale was tested by confirmatory factor analysis. The Cronbach alpha reliability coefficients of the sub-dimensions of the scale vary between 0.71 and 0.77 , and the Cronbach alpha reliability coefficient for the whole scale is 0.90 . In addition, the test-retest reliability coefficient of the scale was calculated as 0.88 (Eminoğlu \& Nartgün, 2009). In this study, Cronbach-alpha internal consistency coefficient calculated for the "Academic Dishonesty Tendencies Scale" of university students was 0.74 .

\section{Brief fear of negative evaluation scale}

The Brief Fear of Negative Evaluation Scale-BFNE is a scale form developed by Leary (1983) and adapted by Çetin, Doğan and Sapmaz (2010) to measure pre-service teachers' fear of negative evaluation. It consists of 11 items, and is a 5-point Likert type scale scored as (1) Absolutely Inappropriate, (2) Inappropriate, (3) Somewhat Appropriate, (4) Appropriate, (5) Absolutely Appropriate. The Cronbach alpha internal consistency coefficient of this single-factor scale is 0.74 and its validity and reliability are accepted. In this study, Cronbach-alpha internal consistency coefficients calculated for the "Brief Fear of negative evaluation Scale" of university students were 0.74 .

\section{Collection and analysis of data}

The data were collected by the researcher in the Fall semester of the Academic Year 2019-2020. Participation in the study was on a voluntary basis. The data in the research were collected in about 15 minutes by paper and pencil. The data obtained in the research were analyzed by using the SPSS 22.0 package program. As a result of the analysis performed with the Kolmagorov Smirnov test, it was found that the data were normally distributed. Independent-Samples T Test, One-Way ANOVA, Pearson Correlation and Simple Linear Regression Analysis were used in data analysis. As a result of the analyses made in this direction, the significance level was accepted as .05 in the comparisons.

\section{Findings}

Findings related to data:

Table 2. Distribution of the mean scores of the participants on the scales

\begin{tabular}{llll}
\hline Scales and sub-dimensions & $\mathbf{n}$ & $\overline{\mathbf{x}}$ & Sd \\
\hline Cheating (ADTS F1) & 306 & 2.58 & 1.47 \\
\hline Assignment and project (ADTS F2) & 306 & 3.09 & 1.40 \\
\hline Research and Reporting (ADTS F3) & 306 & 2.51 & 1.38 \\
\hline Dishonesty in Citations (ADTS F4) & 306 & 3.04 & 1.41 \\
\hline Total Academic Dishonesty Tendency (ADTS TOTAL) & 306 & 2.81 & 1.42 \\
\hline Fear of negative evaluation (BFNE) & 306 & 2.80 & 1.31 \\
\hline
\end{tabular}


When Table 2 is examined, it is seen that academic dishonesty tendencies of the students are at a medium level with $\overline{\mathrm{x}}=2.81$ and also their fear of negative evaluation are at a medium level with $\bar{x}=2.80$ mean points. Considering the sub-dimensions of the academic dishonesty tendency scale, both the dishonesty tendency in the citations are at a high level with $\bar{x}=3.04$ and the assignment-project dishonesty tendencies are at a high level with $\overline{\mathrm{x}}=3.09$ mean points.

Table 3. T test results for the significant difference in students' fear of negative evaluation and academic dishonesty tendencies according to their gender

\begin{tabular}{|c|c|c|c|c|c|c|c|}
\hline & Gender & $\mathbf{n}$ & $\overline{\mathbf{x}}$ & Sd & $\mathbf{t}$ & Df & $\mathbf{p}$ \\
\hline \multirow{2}{*}{$\begin{array}{l}\text { Cheating } \\
\text { (ADTS F1) }\end{array}$} & Female & 135 & 2.61 & 1.04 & \multirow{2}{*}{0.53} & \multirow{2}{*}{304} & \multirow{2}{*}{.60} \\
\hline & Male & 171 & 2.55 & 0.87 & & & \\
\hline \multirow{2}{*}{$\begin{array}{l}\text { Assignment and Project } \\
\text { (ADTS F2) }\end{array}$} & Female & 135 & 3.11 & 1.40 & \multirow{2}{*}{0.64} & \multirow{2}{*}{304} & \multirow{2}{*}{.52} \\
\hline & Male & 171 & 3.07 & 1.40 & & & \\
\hline \multirow{2}{*}{$\begin{array}{l}\text { Research and Reporting } \\
\text { (ADTS F3) }\end{array}$} & Female & 135 & 2.56 & 1.41 & \multirow{2}{*}{1.03} & \multirow{2}{*}{304} & \multirow{2}{*}{.30} \\
\hline & Male & 171 & 2.47 & 1.34 & & & \\
\hline \multirow{2}{*}{$\begin{array}{l}\text { Dishonesty in Citations } \\
\text { (ADTS F4) }\end{array}$} & Female & 135 & 3.09 & 1.43 & \multirow{2}{*}{1.19} & \multirow{2}{*}{304} & \multirow{2}{*}{.23} \\
\hline & Male & 171 & 2.99 & 1.39 & & & \\
\hline \multirow{2}{*}{$\begin{array}{l}\text { Brief Fear of Negative } \\
\text { Evaluation (BFNE) }\end{array}$} & Female & 135 & 2.75 & 0.68 & \multirow{2}{*}{-0.21} & \multirow{2}{*}{304} & \multirow{2}{*}{.23} \\
\hline & Male & 171 & 2.85 & 0.71 & & & \\
\hline
\end{tabular}

When Table 3 is examined, it was determined that there was no significant difference ( $p$ > 0.05) between the "Fears of Negative Evaluation" and the sub-dimensions of the "Academic Dishonesty Tendencies" in terms of gender.

Table 4. $T$ test results related to the difference in students' fear of negative evaluation and academic dishonesty tendencies according to their sports status

\begin{tabular}{|c|c|c|c|c|c|c|c|}
\hline & Sports Level & $\mathbf{n}$ & $\overline{\mathbf{x}}$ & Sd & $\mathbf{t}$ & Df & $\mathbf{p}$ \\
\hline \multirow{2}{*}{$\begin{array}{l}\text { Cheating Tendency } \\
\text { (ADTS F1) }\end{array}$} & Sedentary & 225 & 2.61 & 0.97 & \multirow{2}{*}{1.02} & \multirow{2}{*}{304} & \multirow{2}{*}{0.31} \\
\hline & Athlete & 81 & 2.48 & 0.85 & & & \\
\hline \multirow{2}{*}{$\begin{array}{l}\text { Assignment and Project } \\
\text { (ADTS F2) }\end{array}$} & Sedentary & 225 & 3.09 & 0.60 & \multirow{2}{*}{0.19} & \multirow{2}{*}{304} & \multirow{2}{*}{0.84} \\
\hline & Athlete & 81 & 3.07 & 0.59 & & & \\
\hline \multirow{2}{*}{$\begin{array}{l}\text { Research and Reporting } \\
\text { (ADTS F3) }\end{array}$} & Sedentary & 225 & 2.51 & 0.83 & \multirow{2}{*}{-0.03} & \multirow{2}{*}{304} & \multirow{2}{*}{0.97} \\
\hline & Athlete & 81 & 2.51 & 0.84 & & & \\
\hline \multirow{2}{*}{$\begin{array}{l}\text { Dishonesty in Citations } \\
\text { (ADTS F4) }\end{array}$} & Sedentary & 225 & 3.10 & 0.71 & \multirow{2}{*}{2.60} & \multirow{2}{*}{304} & \multirow{2}{*}{$0.01 *$} \\
\hline & Athlete & 81 & 2.86 & 0.72 & & & \\
\hline \multirow{2}{*}{$\begin{array}{l}\text { Brief Fear of Negative } \\
\text { Evaluation (BFNE) }\end{array}$} & Sedentary & 225 & 2.82 & 0.70 & \multirow{2}{*}{0.71} & \multirow{2}{*}{304} & \multirow{2}{*}{0.48} \\
\hline & Athlete & 81 & 2.76 & 0.68 & & & \\
\hline
\end{tabular}

When Table 4 is examined, it is understood that it intends to check whether there is a significant difference in academic dishonesty levels and fear of negative evaluation according to the students' state of doing sports. It is seen that there is a significant difference only in the "Dishonesty Tendency in Citations" sub-dimension of the academic dishonesty scale according to the students' sports status $(\mathrm{p}<0.05)$. Sedentary students' mean scores of dishonesty in citations $\left(\mathrm{x}^{-}=3.10\right)$ is higher than the score $(\bar{x}=2.86)$ of the students doing sports. In other sub-dimensions of the scale, no difference was found $(p>0.05)$. 
Table 5. One-Way ANOVA results regarding fear of negative evaluation and academic dishonesty tendencies according to the variable of grade level of the participants

\begin{tabular}{|c|c|c|c|c|c|c|c|c|}
\hline \multirow{2}{*}{ Scales and Sub-dimensions } & \multirow{2}{*}{ Grade Level } & \multirow{2}{*}{$\mathbf{n}$} & \multirow{2}{*}{$\overline{\mathbf{x}}$} & \multirow{2}{*}{ Sd } & \multicolumn{2}{|c|}{ Levene Test } & \multirow{2}{*}{$\mathbf{F}$} & \multirow{2}{*}{$\mathbf{p}$} \\
\hline & & & & & statistics & $\mathbf{p}$ & & \\
\hline \multirow{4}{*}{ Cheating } & $1^{\text {st }}$ grade & 89 & 11.96 & 4.19 & \multirow{4}{*}{2.82} & \multirow{4}{*}{0.04} & \multirow{4}{*}{1.84} & \multirow{4}{*}{.13} \\
\hline & $2^{\text {nd }}$ grade & 46 & 13.30 & 4.48 & & & & \\
\hline & $3^{\text {rd }}$ grade & 38 & 12.65 & 4.35 & & & & \\
\hline & $4^{\text {th }}$ grade & 133 & 13.41 & 5.18 & & & & \\
\hline \multirow{4}{*}{ Assignment and Project } & $1^{\text {st }}$ grade & 89 & 22.53 & 3.07 & \multirow{4}{*}{2.58} & \multirow{4}{*}{0.05} & \multirow{4}{*}{2.47} & \multirow{4}{*}{.06} \\
\hline & $2^{\text {nd }}$ grade & 46 & 20.70 & 4.13 & & & & \\
\hline & $3^{\text {rd }}$ grade & 38 & 21.63 & 4.39 & & & & \\
\hline & $4^{\text {th }}$ grade & 133 & 21.28 & 4.70 & & & & \\
\hline \multirow{4}{*}{ Research and Reporting } & $1^{\text {st }}$ grade & 89 & 9.51 & 2.89 & \multirow{4}{*}{3.41} & \multirow{4}{*}{0.01} & \multirow{4}{*}{1.42} & \multirow{4}{*}{.24} \\
\hline & $2^{\text {nd }}$ grade & 46 & 9.85 & 3.25 & & & & \\
\hline & $3^{\text {rd }}$ grade & 38 & 10.53 & 3.38 & & & & \\
\hline & $4^{\text {th }}$ grade & 133 & 10.32 & 3.58 & & & & \\
\hline \multirow{4}{*}{ Dishonesty in Citations } & $1^{\text {st }}$ grade & 89 & 18.42 & 3.86 & \multirow{4}{*}{0.71} & \multirow{4}{*}{0.54} & \multirow{4}{*}{1.11} & \multirow{4}{*}{.35} \\
\hline & $2^{\text {nd }}$ grade & 46 & 17.35 & 4.43 & & & & \\
\hline & $3^{\text {rd }}$ grade & 38 & 17.68 & 4.67 & & & & \\
\hline & $4^{\text {th }}$ grade & 133 & 18.53 & 4.50 & & & & \\
\hline \multirow{4}{*}{ Brief Fear of Negative Evaluation } & $1^{\text {st }}$ grade & 89 & 30.75 & 6.78 & \multirow{4}{*}{-1.13} & \multirow{4}{*}{0.34} & \multirow{4}{*}{0.67} & \multirow{4}{*}{.57} \\
\hline & $2^{\text {nd }}$ grade & 46 & 30.67 & 7.97 & & & & \\
\hline & $3^{\text {rd }}$ grade & 38 & 29.40 & 6.90 & & & & \\
\hline & $4^{\text {th }}$ grade & 133 & 31.35 & 8.23 & & & & \\
\hline
\end{tabular}

When Table 5 is examined; no statistically significant difference ( $p>0.05)$ was determined in the "Fear of Negative Evaluation" scale and all sub-dimensions of "Academic Dishonesty" scale according to the grade level of the students.

Table 6. Correlation Test results showing the relationship between fear of negative evaluation levels and academic dishonesty tendencies

\begin{tabular}{llllll}
\hline Variable & ADTS F1 & ADTS F2 & ADTS F3 & ADTS F4 & BFNE \\
\hline 1.Cheating Tendency (ADTS F1) & 1 & & & & \\
2.Assignment and Project Dishonesty Tendency & & & & & \\
(ADTS F2) & $.165^{* *}$ & 1 & & & \\
3.Research and Reporting Dishonesty (ADTS F3) & $.480^{* *}$ & $.351^{* *}$ & 1 & & \\
4. Dishonesty Tendency in Citations (ADTS F4) & $.416^{* *}$ & $.430^{* *}$ & $.542^{* *}$ & 1 & \\
5. Brief Fear of Negative Evaluation (BFNE) & $.287^{* *}$ & $.255^{* *}$ & $.246^{* *}$ & $.252^{* *}$ & 1 \\
\hline
\end{tabular}

** $\mathrm{p}<.01 \quad * \mathrm{p}>.05$

When Table 6 is examined, according to the results of the Pearson Correlation analysis, it is seen that there is a statistically low, positively significant relationship between the "Fear of negative evaluation" scale and the sub-dimensions of the "Academic Dishonesty Tendencies" scale. When these relationships are examined, it is seen that the highest relationship is between fear of negative evaluation and the cheating tendency sub-dimension $(r=.287, p$ $<.01$ ), which is followed, respectively, by the sub-dimension of dishonesty tendency in assignment and project $(\mathrm{r}=.255, \mathrm{p}<.01)$, sub-dimension of dishonesty tendency in citations $(\mathrm{r}$ $=.252, \mathrm{p}<.01)$, sub-dimension of dishonesty in research and reporting $(\mathrm{r}=.246, \mathrm{p} .<.01)$. 
Table 7. Linear Regression Analysis Results Related to the Effect of Negative Evaluation on Academic Dishonesty

\begin{tabular}{lllll}
\hline Variable & B & Sd & t & p \\
\hline Constant & 45.212 & 2.731 & 16.557 & .000 \\
Fear of negative evaluation & 0.568 & 0.086 & 6.610 & .000 \\
\hline $\mathrm{R}=0.354$ & $\mathrm{R}^{2}=0.123$ & & \\
$\mathrm{~F}(1.305)=43.689$ & $\mathrm{p}=0.000$ & Durbin-Watson=1.891 & \\
\hline
\end{tabular}

When Table 7 is examined, it is determined that there is no autocorrelation between the dependent variable (academic dishonesty) and the independent variable (negative evaluation) since the Durbin Watson value is greater than 1.5 and close to 2, and the relationship between the dependent variable and the independent variable is not false. The fact that Durbin-Watson value is close to 2 indicates that Regression analysis can be performed on the data. Generally, a Durbin-Watson test value of 1.5-2.5 indicates that there is no autocorrelation (Kalayc1, 2005). It was determined that the relationship between fear of negative evaluation and academic dishonesty tendency was significant $(\mathrm{F}(1,305)=43,689 \mathrm{p}<0.01 \mathrm{p}=0,000)$ and negative evaluation alone explained $12.3 \%$ of academic dishonesty $\left(R^{2}=0,123\right)$. According to regression analysis results, regression equation for predicting academic dishonesty trend is: Academic dishonesty $=45.21+0.568 *$ fear of negative evaluation. According to this equation, it is seen that increasing the fear of negative evaluation by one unit positively affects the tendency towards academic dishonesty with a power of 0.568 .

\section{Conclusion and Discussion}

As a result of the data obtained from the study, it was concluded that there was no statistically significant difference in the sub-dimensions of academic dishonesty tendency scale among the participants according to the gender variable. When the literature is examined, there are studies that are in parallel with our study. In their study, Kad1, Baytekin and Arslan (2016) examined academic dishonesty levels and concluded that there was no significant difference between teacher candidates' academic dishonesty levels in terms of gender variable. On the other hand, there are studies in which men are more prone to academic dishonesty than women (Eminoğlu Küçüktepe, 2011; Eminoğlu Küçüktepe \& Küçüktepe, 2012; Tadesse \& Getachew, 2010; Yangın \& Kahyaoğlu 2009). This result can be explained by the close levels of desire of both genders to maintain their place in their social environment and to strengthen them further.

In another result of the study, it was concluded that there was no statistically significant difference between the participants in the fear of negative evaluation scale according to the gender variable. When the literature is examined, it is seen that Ünal, Arık and Uzun (2016), in their study on university students, stated that the gender variable did not have a significant effect on fear of negative evaluation. In the study conducted by Erkan, Gürçay and Çam (2002) on adolescents, it was concluded that there was no significant relationship between the gender variable and fear of negative evaluation. On the other hand, La Greca and Lopez (1998), in their study on measuring the fear of negative evaluation, concluded that the fear of negative evaluation of women was higher than that of men. Ayan and Ünsar (2015), in their study investigating students' levels of fear of negative evaluation, stated that female students had higher mean scores for negative evaluation compared to male students, and that female students had higher academic dishonesty tendencies compared to male students. This result may be due to different sample groups in the studies.

A significant difference was found between the scores of sedentary students and students 
engaged in sports, in the dishonesty tendency in citations, which is a sub-dimension of the academic dishonesty tendencies scale, according to the participants' sports status. Sedentary students' fear of negative evaluation is significantly higher compared to students who do sports. When the literature is examined, studies on academic dishonesty and negative evaluation according to the variable of doing sports are quite limited. Gümüşgül, Üstün, Iş1k and Demirel (2013) stated in their study, where they examined the academic dishonesty tendencies of the participants according to the departments they studied, that the mean scores of the students who do sports are higher than those who do not. This result is in line with the present study. The reason for the low mean scores of students who do sports in the current study may be due to the fact that students who do sports have the opportunity to express their emotions through sports activities, and they have self-esteem, self-confidence and accept that failure is normal as well as success, compared to sedentary individuals, and also they have more developed capacity to cope with emotions such as anxiety, stress, shyness, and alike. What is more, as the term 'sportsmanship' suggests, individuals who are interested in doing sports may tend to be more fair and respectful toward others.

It was concluded that there was no statistically significant difference in fear of negative evaluation scale according to the grade variable. When the literature is examined, the results of the studies are in line with the current study. In the study conducted by Alkan and ÇoklukBökeoğlu (2015) on secondary school students, it was concluded that there was no significant difference between the grade level variable and the students' fear of negative evaluation. In the study by Ercanlar (2019), it was stated that there was no significant difference between the grade variable and the negative evaluation scale. In their study on university students, Ünal, Arik and Uzun (2016) concluded that grade level variables do not have a significant effect on fear of negative evaluation. In the study of Çam, Sevimli and Yerlikaya (2010), in which they determined the reliability and validity levels of the fear of negative evaluation scale, it was concluded that the mean scores obtained from the scale did not create any significance in terms of the grade variable. It was concluded that there was no statistically significant difference in the sub-dimensions of the academic dishonesty tendency scale according to the grade variable. When the literature was examined, Keçeci, Bulduk, Oruç and Çelik (2011) found in their study on nursing students that academic dishonesty tendencies did not differ significantly according to the grade variable. This result in the present study can be explained by the fact that the social anxiety levels of university students are close to each other regardless of their grade level.

According to the results of the regression analysis between the fear of negative evaluation scale and the sub-dimensions of the academic dishonesty tendencies scale which were applied to the students, it is seen that there is a statistically positive low level significant relationship between the dimensions. As students' fear of negative evaluation increases, their academic dishonesty tendencies also increase. As a result, students are subject to continuous evaluation in their education life. Individuals who think that they will fail in the exam and who are concerned about being ridiculed may tend to have academic dishonesty in order to maintain their position in their social environment. Fear of negative evaluation brings with it many negative effects such as trait anxiety, decreased self-esteem and depression in individuals. The present research is considered important in revealing the relationship between fear of negative evaluation and academic dishonesty tendencies of university students and showing that it can be a tool in reducing social anxiety of university students. 


\section{Recommendations}

The research can be repeated using mixed research methods with different sample groups to determine all factors underlying fear of negative evaluation and academic dishonesty behavior. According to the results of the research, it is seen that individuals who do sports have lower levels of negative evaluation. For this reason, sports activities can be planned at universities and students can be encouraged to participate in these activities.

\section{Limitations of the Study}

This study has some limitations regarding its results. The data in this study are limited to the sample group that was created using easily accessible sampling method at Yozgat Bozok University in the fall semester of the academic year 2019-2020.

\section{References}

Bozdoğan, A. E., \& Öztürk, Ç. (2008). Why do teacher' candidates cheat. Elementary Education Online, 7(1).

Alkan, V., \& Çokluk-Bökeoğlu, Ö. (2015). Development of the scale of fear of negative evaluation in academic environments. Eurasian Journal of Social and Economic Studies, 7(5), 302-318.

Aluede, O., Omoregie, E. O., \& Osa-Edoh, G. I. (2006). Academic dishonesty as a contemporary problem in higher education: How academic advisers can help. Reading Improvement, 43(2), 97-107.

Ayan, A., \& Ünsar, A. S. (2015). Determining the levels of fear of negative evaluation: research on students of a public university. Manas Journal of Social Research, 4(5), 263-277.

Çam, S., Sevimli, D., \& Yerlikaya, E. (2010). A validity and reliability study related to the negative evaluation fear scale (NEFS). Çukurova University Journal of Social Sciences Institute, 19(1), 132-140.

Çetin, B., Doğan, T., \& Sapmaz, F. (2010). The Turkish adaptation of brief fear of negative evaluation scale: the validity and reliability study. Education and Science, 35(156), 205-216.

Çetin, B., İlhan, M. \& Y1lmaz, F. (2014). Fear of negative evaluation and academic the relationship between risk taking with canonical correlation investigation, Educational Sciences: Theory \& Practice, 14(1), 135-158.

Cihan, B. B., \& Araç Ilgar, E. (2018). Sports and non-sports (sedentary) high school students determining curiosity levels. Journal of Ahi Evran University Kırşehir Faculty of Education, 19(2), 1649-1660. https://doi.org/10.29299/kefad.2018.19.02.016.

Colnerud, G., \& Rosander, M. (2009) Academic dishonesty, ethical norms and learning. Assessment ve Evaluation in Higher Education, 34(5), 505-517. https://doi.org/10.1080/02602930802155263.

Crown, D. F., \& Spiller, M. S. (1998). Learning from the literature on collegiate cheating: A review of empirical research. Journal of Business Ethics, 17, 683- 700.

Dilbaz, N. (1997). Social phobia. Psychiatry World, 1(1), 18-24.

Emınoğlu Küçüktepe, S. (2011). Evaluation of tendency towards academic dishonesty levels of psychological counseling and guidance undergraduate students. Procedia Social and Behavioral Sciences, 15, 2722-2727. https://doi.org/10.1016/j.sbspro. 2011.04.177. 
Emınoğlu Küçüktepe, S., \& Küçüktepe, C. (2012). Tendencies of history teacher candidates to make copies an examination of various variables. Journal of Hasan Ali Yücel Faculty of Education, 9(1), 115-125.

Eminoğlu, E., \& Nartgün, Z. (2009). A scale development study to measure academic dishonesty tendency of university students. International Journal of Human Sciences, 6(1), 215-240.

Ercanlar, M. (2019). The fear of negative evaluation and self-efficacy beliefs of french foreign language students. Anadolu University Journal of Education Faculty (AUJEF), 3(4), 239-252. https://doi.org/10.34056/aujef.441565.

Erkan, Z., Gürçay, S., \& Çam, S. (2002). Parent and father attitudes and investigation in terms of gender. Çukurova University Journal of Social Sciences Institute, 10(10): 64-75.

Gerdeman, D. R. (2000). Academic dishonesty and the community college. Los Angeles: Eric Digest.

Gümüşgül, O., Üstün, Ü. D., Utku, Işık., \& Demirel, D. H. (2013). Evaluation of academic dishonesty level of students studying at school of physical education and sports. Spormetre The Journal of Physical Education And Sport Sciences, 11(2), 131-138. https://doi.org/10.1501/Sporm_0000000246

İnan, S. A., İnan, M., Varol, Y. K., Çolakoğlu, F. F., \& Çolakoğlu, T. (2019). The relationship between social appearance anxiety and attitudes towards physical education lesson and trait anxiety levels of BİLSEM and secondary school students. Niğde University Journal of Physical Education and Sport Sciences, 13(2), 145-151.

Irmak, M. (2015). An examination of secondary level students' fear of negative evaluation and their attitudes towards learning. (Unpublished master's thesis). Erciyes University, Kayseri.

Kadı A., Baytekin O. F., \& Arslan H. (2016). Academic dishonesty tendencies and values of teacher candidates. Journal of Higher Education and Science, 6(3), 396-401. Doi $=10.5961 /$ jhes. 2016.176

Kalaycı, Ş. (2010). SPSS uygulamalı çok değişkenli istatistik teknikleri [Multivariate statistical technique with SPSS]. Ankara: Asil Yayın Dağıtım.

Karasar, N. (2015). Bilimsel araştırma yöntemi [Scientific research methods]. Ankara: Nobel Yayınc1lık.

Keçeci, A., Bulduk, S., Oruç, D., \& Çelik, S. (2011). Academic dishonesty among nursing students: A descriptive study. Nursing Ethics, 18(5), 725-733. https://doi.org/10.1177/0969733011408042.

Kıral B., \& Saracaloğlu B. (2018). The relationship between academic dishonesty tendency and fear of negative evaluation. YYU Journal of Education Faculty, 15(1), 323-359. http://dx.doi.org/10.23891/efdyyu.2018.71.

La Greca, A. M., \& Lopez, N. (1998). Social anxiety among adolescents: Linkages with peer relations and friendships. Journal of Abnormal Child Psychology, 26(2), 83-94.

Leary, M.R. (1983). A brief version of the fear of negative evaluation scale. Personality and Social Psychology Bulletin, 9(3), 371-375. http://dx.doi.org/10.1177/ 0146167283093007.

Maramark, S., \& Maline, M. B. (1993). Academic dishonesty among college students. Issues in Education. https://files.eric.ed.gov/fulltext/ED360903.pdf.

Monfries, M. M., \& Kafer, N. F. (1994). Private self-consciousness and fear of negative evaluation. The Journal of Psychology, 128(4), 447-453.

Murdock, T. B., \& Anderman, E. M. (2006). Motivational perspectives on student cheating: Toward an integrated model of academic dishonesty. Educational Psychologist, 41(3), 129-145. https://doi.org/10.1207/s15326985ep4103_1 
Nichols, R. (2014). Academic expectations of a high school and the frequency of academic dishonesty as reported by high school principals in Virginia (Doctoral dissertation). Virginia Polytechnic Institute and State University, Virginia.

Odabaşı, H. F., Birinci, G., Kılıçer, K., Şahin, M. C., Akbulut, Y., \& Şendağ, S. (2007). Academic dishonesty: getting easier with internet and ICT. Anadolu University Journal of Social Sciences, 7(1), 503-518.

Ömur, Y. E., Aydin, R., \& Argon, T. (2014). Relationship between prospective teachers' fear of negative evaluation and their academic dishonesty tendencies. Journal of Education and Humanities: Theory and Practice, 5(9), 131-149.

Subaş1, G. (2009). Social anxiety differences and peer relations in adolescents: According to sociometric status grups. Ege Education Journal, 10(1),1-23.

Tadesse, T., \& Getachew, K. (2010). An exploration of undergraduate students' self-reported academic dishonesty at Addis Ababa and Jimma Universities. Ethiopian Journal of Education and Science, 5(2), 79-99.

Ünal, E., Arık, S., \& Uzun, B. (2016). Negative evaluation fears of teacher candidates studying at the departments of primary school teaching and social studies education. Adryaman University Journal of Social Sciences Institute, 22, 289-307.

Ünal, Y., \& Uçak, N. Ö (2017). Views and behaviors of university students from different educational and cultural settings towards plagiarism. Journal of Faculty of Letters, 34(1), 177-194

Watson, D., \& Friend, R. (1969). Measurement of social-evaluative anxiety. Journal of Consulting and Clinical Psychology, 33(4), 448-457.

Weeks, J. W., Heimberg, R. G., Fresco, D. M., Hart, T. A., Turk, C. L., Scneider, F. R., \& Liebowitz, M. R. (2005). Empirical validation and psychometric evaluation of the brief fear of negative evaluation scale in patients with social anxiety disorder. Psychological Assessment, 17(2), 179-190. https://doi.org/10.1037/10403590.17.2.179.

Yangın, S., \& Kahyaoğlu, M. (2009) Attitudes and ideas of candidate primary school teachers towards copying. Balikesir University Journal of Social Sciences Institute, 12(21), 4655. 